\title{
Characterization of a new duplicate $\delta$-opioid receptor from zebrafish
}

\section{Noelia Pinal-Seoane*, Ivan Rodríguez Martin*, Veronica Gonzalez-Nuñez*, Ezequiel Marron Fernandez de Velasco, Francisco Alvar Alvarez, Rogelio Gonzalez Sarmiento ${ }^{1}$ and Raquel E Rodriguez}

\author{
Department of Biochemistry and Molecular Biology, Faculty of Medicine, Instituto de Neurociencias de Castilla y Leon (INCYL), University of Salamanca, \\ Avda. Alfonso X 'El Sabio' s/n, 37007 Salamanca, Spain \\ ${ }^{1}$ Department of Medicine, Faculty of Medicine, University of Salamanca, Salamanca, Spain
}

(Requests for offprints should be addressed to RE Rodriguez; Email: requelmi@usal.es)

*(N Pinal-Seoane, I R Martin and V Gonzalez-Nuñez contributed equally to this work)

\begin{abstract}
A new full-length cDNA (ZFOR4) that encodes an opioid receptor has been isolated from the teleost zebrafish. The encoded polypeptide is 375 amino acids long and shows high sequence similarity to other $\delta$-opioid receptors, including ZFOR1, the other $\delta$-opioid receptor from zebrafish previously characterized by us. In situ hybridization studies have revealed that ZFOR4 mRNA is highly expressed in particular brain areas that coincide with the expression of the $\delta$-opioid receptor in other species. Pharmacological analysis of ZFOR4 shows specific and saturable binding with $\left[{ }^{3} \mathrm{H}\right]$ diprenorphine, displaying one binding site with $K_{\mathrm{D}}=3.42 \pm 0.38 \mathrm{nM}$ and a receptor density of $6231 \pm 335 \mathrm{fmol} / \mathrm{mg} \mathrm{protein}$. Competition-binding experiments were performed using $\left[{ }^{3} \mathrm{H}\right]$ diprenorphine and several unlabelled ligands (peptidic and non-peptidic). The order of affinity obtained is Met-enkephalin $>$ Naloxone $>$ Leu-enkephalin $>$ Dynorphin A $\gg$ BW373U86 $>$ Morphine $\gg\left[D-P e{ }^{2}\right.$, D-Pen ${ }^{5}$-Enkephalin, U69,593. $\left[{ }^{35}\right.$ S]GTP $\gamma$ S stimulation studies show that the endogenous ligands Met- and Leu-enkephalin and the non-peptidic $\delta$ agonist BW373U86 were able to fully activate ZFOR4. Our results prove the existence of two functional duplicate genes of the $\delta$-opioid receptor in the teleost zebrafish.
\end{abstract}

Journal of Molecular Endocrinology (2006) 37, 391-403

\section{Introduction}

At present, morphine, the major active alkaloid of opium, remains one of the most important compounds used in medicine for the treatment of chronic pain. Nevertheless, opioid administration produces, besides its positive effects, severe side effects like hypotension, constipation and hypothermia (Pasternak 1988, Craft et al. 2000). In addition to this, the illegal abuse of opioids, heroin in particular, represents one of the devastating social problems of our time. Hence, the elucidation of the mechanisms involved in opioid activity should be considered a priority in this field of research.

Although the main body of research on opioid receptors has been performed on mammalian models, the presence of opioids and their receptors in other phyla was suggested shortly after their discovery (Pert et al. 1974, Simantov et al. 1976). Pharmacological and immunohistochemical data point towards the existence of an opioid system in birds, teleosts (Bird et al. 1988, Dores et al. 2002) and even in invertebrates (Harrison et al. 1994), but the role that opioid receptors play in the biology of such organisms remains obscure. It has been proposed that the opioid system arose as an immunomodulatory system in invertebrates and that the analgesic properties exhibited by these molecules were developed later in evolution, when pain was recognized as an alerting process (Stefano et al. 1998).

An approach to the problem of understanding why opioid drugs can cause tolerance and dependence is to develop and use new animal models, which would provide findings that could be extrapolated to higher vertebrates and ultimately to humans. The zebrafish has been widely and successfully used in molecular and developmental biology (Ingham 1997, Fishman 2001, Golling et al. 2002, Pichler et al. 2003) and has also been proved as a valid model to study the effects of some drugs of abuse, such as cocaine (Darland \& Dowling 2001) and ethanol (Dlugos \& Rabin 2003). Our group has studied the zebrafish opioid system and we have characterized several receptors (Barrallo et al. 2000, Rodriguez et al. 2000) and five opioid propeptide genes (Gonzalez-Nuñez et al. 2003a,b,c) so far. Our previous results indicate that the zebrafish receptors as well as the endogenous peptides are similar to their mammalian homologues, thus indicating that the opioid system has been well conserved throughout the evolution of vertebrates. Hence, we propose the zebrafish as an 
organism, where the study of the opioid system and its interactions with different drugs can be easily evaluated in basic research and that the results can be applied to the mammalian opioid system.

Opioid receptors are classified according to their pharmacological profile into three different types, namely $\mu, \delta$ and $\kappa$. Several investigators have shown that the analgesic effect of morphine mainly depends on its action on the $\mu$-opioid receptor, although morphine also seems to bind to the $\delta$ - and $\kappa$-opioid receptors (for review, see Waldhoer et al. 2004).

In an attempt to shed light on the biological role of the $\delta$-opioid receptor and to investigate its phylogeny, we have isolated a full-length cDNA from the zebrafish Danio rerio, which corresponds, from molecular comparison, to the $\delta$-type of opioid receptor. We present here the sequence, genomic structure, expression, pharmacology and G-protein activation of this new duplicate of the $\delta$-opioid receptor that has been conserved during the course of vertebrate evolution and that may represent a new model for studying opioid mechanisms that control pain and drug-induced behaviour.

\section{Materials and methods}

\section{Animals}

Adult zebrafish $D$. rerio were obtained from a local pet supplier, maintained at $25-28^{\circ} \mathrm{C}$ and fed once a day. In all experiments fish from both sexes were used. Animals were handled according to the guidelines of the European Communities Council directive of 24 November 1986 (86/609/EEC) and in all cases, were treated in accordance with the declaration of Helsinki and/or with the Guide for the Care and Use of Laboratory Animals as adopted and promulgated by the US National Institutes of Health and the Current Spanish Legislation (BOE 67/8509-12, 1998).

\section{Cloning techniques}

To clone the ZFOR4 receptor, we have followed the methodology prescribed by Barrallo et al. (2000). Briefly, a $\kappa$-opioid receptor fragment was cloned by reverse transcriptase (RT)-PCR using total RNA from mouse brain as template and labelled with $\left[{ }^{32} \mathrm{P}\right] \mathrm{dCTP}$ by the random primer method (Redi prime II Ready to Go Labelling kit; Amersham Pharmacia Biotech). A ZIPLOX cDNA library from adult zebrafish brain (GIBCO-BRL) was screened using the above-described fragment as a probe. Approximately $5 \times 10^{5}$ pfu were plated and transferred on duplicate nylon membranes (Hybond-N; Amersham). After a $2 \mathrm{~h}$ prehybridization step at $65^{\circ} \mathrm{C}$, hybridization was performed for $16 \mathrm{~h}$ at $65^{\circ} \mathrm{C}$. Filters were washed twice for $30 \mathrm{~min}$ at $39^{\circ} \mathrm{C}$ in $1 \times$ SSC, SDS $0 \cdot 1 \%$ and exposed for $24 \mathrm{~h}$ at $-80^{\circ} \mathrm{C}$ to an autoradiography film (Kodak-X-Omat$\mathrm{AR}$ ) in the presence of an intensifying screen. Positive clones were purified and DNA isolated following standard procedures (Sambrook \& Russell 2001). A $\lambda$-DASH II genomic library from adult zebrafish (courtesy of B Jones and M Petkovich, Queen's University, Canada) was screened using the cDNA previously obtained as a probe. Labelling and hybridization was performed as described previously.

The DNA obtained was digested with the restriction endonucleases EcoRI, BamHI, HindIII and SacI (Promega) and analysed by electrophoresis in agarose gels. Fragments of interest were purified from agarose and ligated in Bluescript plasmid (Stratagene, Madrid, Spain). Inserts were sequenced by dideoxynucleotide chain terminators method (T7 Sequencing kit; Pharmacia).

NCBI PubMed and EMBL websites were visited to obtain information about homologous sequences to the opioid receptors, as well as to search the zebrafish genome. DNA sequences were analysed with Edit View (ABI Automated DNA Sequence Viewer 1.0, PerkinElmer, Madrid, Spain) and DNA Strider $1 \cdot 1$ (Institut de Recherche Fondamentale) software. Oligonucleotides were designed with Oligo 4.05 Primer Analysis Software (National Biosciences, Inc., Plymouth, MN, USA). Homology studies were performed with FASTA or BLAST programs from EMBL website and ClustalW program was used to perform the alignments with other homologous genes.

\section{Expression studies}

To determine the expression pattern of ZFOR4 in the central nervous system (CNS) of zebrafish, we used the in situ hybridization techniques (ISH), using the same methodology that we have previously used to study the expression of ZFOR1, a putative duplicate of ZFOR4 (Porteros et al. 1999). Briefly, adult zebrafish (D. rerio) of both sexes obtained from a local supplier were deeply anaesthetized with tricaine methanesulphonate (MS-222; Sigma) and fixed overnight by immersion in freshly prepared $4 \%$ paraformaldehyde, soaked in $30 \%$ sucrose, serially sectioned on a cryostat (Leica, Microsystems, Barcelona, Spain) in $20 \mu \mathrm{m}$ thickness and finally thawmounted onto gelatine-coated microscope slides. Coronal sections were fixed in $4 \%$ paraformaldehyde, followed by one wash in 1 M PBS (pH 7•4), and dehydration in graded ethanol series $(60,80,90$ and $100 \%)$.

Sense (5'-CAC TTA ATT AGA AGG CGT TCG ACA TAT AGG GGA-3 ${ }^{\prime}$ ) and antisense oligonucleotides $\left(5^{\prime}\right.$-TCC CCT ATA TGT CGA ACG CCT TCT AAT TAA GTG-3') were designed from the cDNA sequence of ZFOR4 (Genbank database Accession number AY262256) at the $5^{\prime}$ region (Fig. 1), the most specific zone for ZFOR4 in comparison with the rest of opioid 
1 ATGGAGCCTCCAACAGTGACTGTCAGCGATTTTTCCGAGCGTTATCCTTTATTTCTGCAC

$\begin{array}{lllllllllllllllllllll}1 & M & E & P & P & T & V & T & V & S & D & F & S & E & R & Y & P & L & F & L & H\end{array}$

61 Å̊TCGAGCTTTCTGGAGGAGCCTGCGGGACTTCTGTCCÅ̊CTGGAGCGGAGGAAGCAGT

$\begin{array}{llllllllllllllllllllll}21 & N & S & S & F & L & E & E & P & A & G & L & L & S & N & W & S & G & G & S & S\end{array}$

121 GAGCTGAAGGCGGTGAGAGGCAGCAGTGCGGTCGCTATCGCTGTCTCCATCACTGCGCTA

$\begin{array}{lllllllllllllllllllll}41 & E & \text { L } & K & A & V & R & G & S & S & A & V & A & I & A & V & S & I & \text { T } & \text { A } & \text { L }\end{array}$

181 TACTCGGTCATCTGCGTTGTGGGACTCGTTGGAAATGTGCTGGTTATGTACGGAGTGGTC

$\begin{array}{lllllllllllllllllllll}61 & \mathbf{Y} & \mathbf{S} & \mathbf{V} & \mathbf{I} & \mathbf{C} & \mathbf{V} & \mathbf{V} & \mathbf{G} & \mathbf{L} & \mathbf{V} & \mathbf{G} & \mathbf{N} & \mathbf{V} & \mathbf{L} & \mathbf{V} & \mathbf{M} & \mathbf{Y} & \mathbf{G} & \mathbf{V} & \mathbf{V}\end{array}$

241 AGGTACACGAAGATGAAAACGGCAACCAACATATACATCTTCAACCTGGCATTAGCAGAT

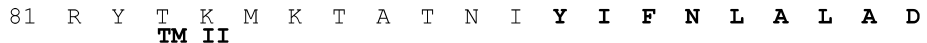

301 GCGTTGGCCACCAGTACATTGCCCTTCCAGAGCGCCAAATACCTCATGGGCACCTGGCCG

$\begin{array}{lllllllllllllllllllll}101 & \text { A } & \text { L } & \mathbf{A} & \mathbf{T} & \mathbf{S} & \mathbf{T} & \mathbf{L} & \mathbf{P} & \mathbf{F} & \mathbf{Q} & \mathbf{S} & \mathbf{A} & \mathrm{K} & \mathrm{Y} & \mathrm{L} & \mathrm{M} & \mathrm{M} & \mathrm{T} & \text { W } & \mathrm{P}\end{array}$

361 TTCGGCGAGCTCTTGTGTAAA GTGGTCATTGCTATTGACTATTACAACATGTTTACCAGT

$\begin{array}{lllllllllllllllllllll}121 & \mathrm{~F} & G & \mathrm{E} & \mathrm{L} & \mathrm{L} & \mathrm{C} & \mathrm{K} & \mathrm{V} & \mathbf{V} & \mathbf{I} & \mathbf{A} & \mathrm{I} & \mathbf{D} & \mathbf{Y} & \mathbf{Y} & \mathbf{N} & \mathbf{M} & \mathbf{F} & \mathbf{T} & \mathbf{S}\end{array}$

421 ATTTTCACGCTGACGATGATGAGTGTGACCGCTATATTGCCGTGTGTCATCCGGTGAGG

$\begin{array}{lllllllllllllllllllll}141 & \text { I } & \mathbf{F} & \mathbf{T} & \mathbf{L} & \mathbf{T} & \mathbf{M} & \mathbf{M} & \mathbf{S} & \mathbf{V} & \mathrm{D} & \mathrm{R} & \mathrm{Y} & \mathrm{I} & \mathrm{A} & \mathrm{V} & \mathrm{C} & \mathrm{H} & \mathrm{P} & \mathrm{V} & \mathrm{R}\end{array}$

481 GCCCTGGACTTCCGCACGCCTGTCAAAGCCAAGATCATCAACATCTGCGTCTGGATTCTG

$\begin{array}{lllllllllllllllllllll}161 & A & L & D & F & R & T & P & V & K & A & K & I & I & N & I & C & V & W & I & L\end{array}$

541 TCCTCCGCTGTCGGCTTCCCCGTCATGGTGATGGCTGTTACTAAAGAATTAGACTCAGGC

$\begin{array}{lllllllllllllllllllll}181 & \mathbf{S} & \mathbf{S} & \mathbf{A} & \mathbf{V} & \mathbf{G} & \mathbf{F} & \mathbf{P} & \mathbf{V} & \mathbf{M} & \mathbf{V} & \mathbf{M} & \mathbf{A} & \mathbf{V} & \mathrm{T} & \mathrm{K} & \mathrm{E} & \mathrm{L} & \mathrm{D} & \mathrm{S} & \mathrm{G}\end{array}$

601 AAAACAATCTGCATGCTGAAATTCCCCGACCCAGAATGGTACTGGGATACAGTGACCAAA

$\begin{array}{lllllllllllllllllllll}201 & K & T & I & C & M & L & K & F & P & D & P & E & W & Y & W & D & T & V & T & K\end{array}$

661 ATCTGCGTTTTTATTTTTGCCTTTGTGTTTCCCGTCCTGGTGATCACCGTCTGCTACGGC

$\begin{array}{lllllllllllllllllllllll}221 & \text { I } & \mathbf{C} & \mathbf{V} & \mathbf{F} & \mathbf{I} & \mathbf{F} & \mathbf{A} & \mathbf{F} & \mathbf{V} & \mathbf{F} & \mathbf{P} & \text { V } & \text { I } & \text { V } & \text { I } & \text { T } & \text { V } & \text { C } & \text { Y } & \text { G }\end{array}$

721 CTGATGATCCTGCGGCTGAAGAGCGTGCGCCTGCTCTCCGGCTCAAAGAGAAGGACAGG

$\begin{array}{lllllllllllllllllllll}241 & \text { L } & \text { M } & \text { I } & \text { L } & R & \text { L } & K & \text { S } & \text { V } & R & \text { L } & \text { L } & \text { S } & G & S & K & E & K & D & R\end{array}$

781 AACCTCCGGCGCATCACCCGCATGGTTTTAGTGGTGGTGGCGCATTCATCATCTGCTGG

$\begin{array}{lllllllllllllllllllll}261 & N & L & R & R & I & T & R & \text { M } & \text { V } & \text { L } & \text { V } & \text { V } & \text { V } & \text { A } & \text { A } & \text { F } & \text { I } & \text { I } & \text { C } & \text { W }\end{array}$

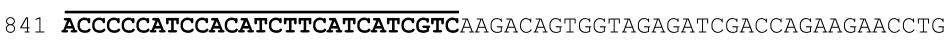

$\begin{array}{llllllllllllllllllllll}281 & \mathbf{T} & \mathbf{P} & \mathbf{I} & \mathbf{H} & \mathbf{I} & \boldsymbol{F} & \mathbf{I} & \mathbf{I} & \mathbf{V} & \mathrm{K} & \mathrm{T} & \mathrm{V} & \mathrm{V} & \mathrm{E} & \mathrm{I} & \mathrm{D} & \mathrm{Q} & \mathrm{K} & \mathrm{N} & \mathrm{L}\end{array}$

901 CTGGTGGTGGCCTGCTGGCATCTGTGCATCGCTCTGGGCTACATGAACAGCAGCCTCAAC

$\begin{array}{lllllllllllllllllllll}301 & \text { L } & \text { V } & \text { V } & \text { A } & \text { C } & \text { W } & \text { H } & \text { L } & \text { C } & \text { I } & \text { A } & \text { L } & \text { G } & \mathbf{Y} & \mathbf{M} & \mathbf{N} & \mathbf{S} & \mathbf{S} & \text { L } & \mathbf{N}\end{array}$

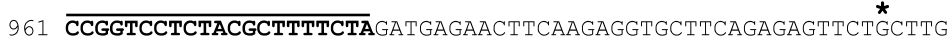

$\begin{array}{lllllllllllllllllllllll}321 & \mathbf{P} & \mathbf{V} & \mathrm{L} & \mathbf{Y} & \mathbf{A} & \mathbf{F} & \mathrm{L} & \mathrm{D} & \mathrm{E} & \mathrm{N} & \mathrm{F} & \mathrm{K} & \mathrm{R} & \mathrm{C} & \mathrm{F} & \mathrm{R} & \mathrm{E} & \mathrm{F} & \mathrm{C} & \mathrm{L}\end{array}$

1021 CCTTTTCGCACTCGCATAGAGCAGAACAGCTTTTCCAAAGCCCGAGCGTCATCAGAGAG

$\begin{array}{lllllllllllllllllllll}341 & \mathrm{P} & \mathrm{F} & \mathrm{R} & \mathrm{T} & \mathrm{R} & \mathrm{I} & \mathrm{E} & \mathrm{Q} & \mathrm{N} & \mathrm{S} & \mathrm{F} & \mathrm{S} & \mathrm{K} & \mathrm{A} & \mathrm{R} & \mathrm{S} & \mathrm{V} & \mathrm{I} & \mathrm{R} & \mathrm{E}\end{array}$

1081 CCCATCTCTGTCTGCGCCAAATCAGAATCAATCAAGCAGCCCACA TGA

$\begin{array}{lllllllllllllllll}361 & \mathrm{P} & \mathrm{I} & \mathrm{S} & \mathrm{V} & \mathrm{C} & \mathrm{A} & \mathrm{K} & \mathrm{S} & \mathrm{E} & \mathrm{S} & \mathrm{I} & \mathrm{K} & \mathrm{Q} & \mathrm{P} & \mathrm{T} & \text { STOP }\end{array}$

ctagacctggaccggatgactcctagtacacagaaagacccgcagtccgaggtaacccagatctctac aactgagttttaagcttatctggcccataaactgctggcagaatgtcatgttggggcattatttatat tttattctcatcgttcttgactgaaaagtatggatggccetgaaatgatctgcgagatattttcctaa gtgaggaaatgagatgatctggaccatcaagatggtaatcatgcattggaaagacatcaaagacctg accaacaggaatttacattcattagcggtatatgagccaatacagcagattccctaatgagattttt tttttatattgcaagttaatgcatttccatgggaattgtgggaattgtgggattttatgatacattga ataatcaattctgctttgaaacaacaaagtgagctgtaagatttttcttacaagagcttgttacaca gaaaatgaaatgactcttttgaagctcctgttgtagacaataaaagtttttttttcttaaaac caagacatatggagaaacattggactttagaatggacattcccttgttttcatggatgtcagcgat gttcttcctttgaaaacataaactctgagcattattcatttcatggtgctttataaagtcaatttgt aaatttgtgctactagtgaaggtgttttaaaaccttgactatgaagtataaacgtttttagctctt tagtatttagtggacgaaaatcttgcatttctttgccattggcgcagaatggctgtttttatgacctt cttcaaattctaaagttgaagtgacatttaacgaatcgtctcatgatgttagtgttggatttaaatg tcagcttactgtaaaggagatggtttagtttcttgagctgtaataggaactttttccagccaagt gtgtttatgtattagttttgcttcctgtattctgcttcactgatctgttctcagcaatctatttta tggacgcatggaaattagacatcacaaactatctgatctgccagtatttgttgtgaaagttcagaaaa

aataattaaatcattctgtagattaaaaaaaaaaaaaaacccgcccggcgagatctcct 2370

Figure 1 Nucleotide and deduced amino acid sequences for the ZFOR4 cDNA, a $\delta$-opioid receptor from zebrafish. The predicted transmembrane domains are underlined and written in bold, the two cysteines that are forming a disulphide bond are marked with \#, the Asn residues that can be glycosylated with $\bullet$, the potential Ser/Thr phosphorylation sites with $¥$ and the putative palmitoylation site with *. The oligonucleotide sequence used as a probe in the expression studies has been italicized and underlined. 
receptor genes in zebrafish. Also, in order to compare the expression of both $\delta$-opioid receptor-like duplicates, ZFOR1 and ZFOR4, the same oligonucleotides (5'-ACC AGT GCG ATG CAA GTG CCA GCT A-3 ${ }^{\prime}$ and 5'-GCA GAC TGT TGT ATT CTG ATT TGT CAC TCT AGT GA-3') used by our group to describe the expression of ZFOR1 (available in EMBL DataBase under Accession number AJ001596) in the CNS of adult zebrafish were used (Porteros et al. 1999). All these oligonucleotides were labelled at $5^{\prime}$ end with digoxigenin and used at a final concentration of $10 \mathrm{ng} / \mu \mathrm{l}$.

Tissue was prehybridized in hybridization buffer (Omnibuff, Wak Chemie, Medical GMBH) for $30 \mathrm{~min}$ at room temperature and hybridized overnight at $37^{\circ} \mathrm{C}$ with the oligonucleotide probes. Sections were then washed in PBS for $10 \mathrm{~min}$, once at $37^{\circ} \mathrm{C}$ and twice at room temperature. Mouse antidigoxigenin antibody diluted in TBS (Tris $50 \mathrm{mM}, \mathrm{NaCl} 800 \mathrm{mM}(\mathrm{pH} \mathrm{7.4)}$ ) was used at $4{ }^{\circ} \mathrm{C}$ overnight for immunological amplification. After washing for $5 \mathrm{~min}$ at room temperature in TBS, sections were incubated in a humid chamber with biotinylated goat antimouse antiserum in TBS for $40 \mathrm{~min}$ and then washed in TBS. Streptavidin-peroxidase conjugate and 3-3'-diaminobenzidine were used for immunological detection. Finally, after dehydration, the slides were mounted with Entellan (Merck). To ensure the specificity of the method, adjacent sections were used as controls. The following approaches were performed: pretreatment with RNase, incubation with sense probe, incubation without probe and incubation prior to hybridization with an excess of non-labelled oligodeoxynucleotide and then hybridization with a labelled one. Absence of signal in adjacent sections hybridized as negative controls confirmed the specificity of the hybridization.

\section{Cell culture and transfection}

The complete cDNA sequence of ZFOR4 was ligated in the mammalian expression vector pcDNA3 and HEK 293 cells were transfected using lipofectamine (Invitrogen) and selected with geneticin $0.5 \mu \mathrm{g} / \mu \mathrm{l}$ (GibCo BRL). After 2 months of selection period, RT-PCR was used to confirm that the positive clones were expressing the ZFOR4 receptor. Stably transfected HEK 293 cells expressing the ZFOR4-opioid receptor were grown in Dulbecco's Modified Eagle Medium (DMEM) supplemented with $10 \%$ fetal calf serum, glutamine $2 \mathrm{mM}$, penicillin $100 \mathrm{U} / \mathrm{ml}$, streptomycin $0 \cdot 1 \mathrm{mg} / \mathrm{ml}$ and geneticin $0 \cdot 25 \mu \mathrm{g} / \mu \mathrm{l}$ at $37^{\circ} \mathrm{C}$ under $5 \% \mathrm{CO}_{2}$ atmosphere (Biotech Galaxy, RS Biotech., Irvine, Scotland, UK).

\section{Pharmacological studies}

Cells were grown to $80 \%$ confluence, harvested in PBS (pH 7.4) containing EDTA $2 \mathrm{mM}$ and collected by centrifugation at $500 \mathrm{~g}$. The cell pellets were resus-

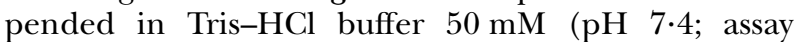
buffer) with protease inhibitors bacitracin $0.1 \mathrm{mg} / \mathrm{ml}$, captopril $3.3 \mu \mathrm{M}$ and thiorphan $0.33 \mu \mathrm{M}$ (Sigma). The cell suspensions were homogenized with a Kinematika polytron in assay buffer, the homogenates were centrifuged at $6000 \mathrm{~g}$ for $15 \mathrm{~min}$ at $4{ }^{\circ} \mathrm{C}$ and the pellets were washed once in assay buffer, homogenized and centrifuged again. Membranes were resuspended in ice-cold assay buffer with protease inhibitors and protein concentration was determined by Lowry method (Onishi and Barr Modification).

To perform the pharmacological studies, the radioligands $\quad\left[{ }^{3} \mathrm{H}\right]$ diprenorphine $\quad(50 \mathrm{Ci} / \mathrm{mmol})$, $\left[{ }^{3} \mathrm{H}\right]$ DPDPE $(50 \mathrm{Ci} / \mathrm{mmol})$ and $\left[{ }^{35} \mathrm{~S}\right] \mathrm{GTP} \gamma \mathrm{S}$ were purchased from Perkin-Elmer, Dupont and PerkinElmer respectively. Morphine was obtained from the Spanish Ministry of Health, naloxone, BW373U86, Metenkephalin; Leu-enkephalin, DPDPE, dynorphin A and U69,593 were purchased from Sigma Aldrich and D-AlaD-Leu-enkephalin from Tocris. For saturation-binding assays, 25-50 $\mu \mathrm{g}$ protein were incubated with different concentrations of the radioligands $\left[{ }^{3} \mathrm{H}\right]$ diprenorphine and $\left[{ }^{3} \mathrm{H}\right]$ DPDPE for $3 \mathrm{~h} 45 \mathrm{~min}$ at $25^{\circ} \mathrm{C}$ in a final volume of $250 \mu$ l. Ten micromolars of naloxone were used to determine non-specific binding. After incubation, the reaction was stopped by adding $4 \mathrm{ml}$ ice-cold assay buffer, the mixture was rapidly filtrated using a Brandel Cell Harvester and washed twice onto GF/B glass-fibre filters that were presoaked with $0 \cdot 2 \%$ polyethylenimine (Sigma) for at least $1 \mathrm{~h}$. The filters were placed in scintillation vials and incubated overnight at room temperature in EcoScint A scintillation liquid. Radioactivity was counted using a Beckman Coulter scintillation counter. All experiments were performed in duplicate and repeated twice.

In competition-binding assays, $\left[{ }^{3} \mathrm{H}\right]$ diprenorphine was displaced by several unlabelled compounds at a concentration range from $0.3 \mathrm{nM}$ to $10 \mu \mathrm{M}$, using $10 \mu \mathrm{M}$ naloxone to determine non-specific binding. All experiments were performed in duplicate and done thrice.

Agonist stimulation of $\left[{ }^{35} \mathrm{~S}\right] \mathrm{GTP} \gamma \mathrm{S}$ binding was performed as described by Traynor \& Nahorski (1995). Twenty micrograms of protein were incubated in a buffer with Tris-HCl $50 \mathrm{mM}$ (pH 7•4), $\mathrm{NaCl} 100 \mathrm{mM}, \mathrm{MgCl}_{2}$ $5 \mathrm{mM}$, EDTA $1 \mathrm{mM}$, DTT $1 \mathrm{mM}$, BSA $0 \cdot 1 \%$, GDP $10 \mu \mathrm{M}$ and $\left[{ }^{35} \mathrm{~S}\right] \mathrm{GTP} \gamma \mathrm{S} 0 \cdot 1 \mathrm{nM}$ in the presence of varying concentrations of opioids ranging from $0 \cdot 1 \mathrm{nM}$ to $10 \mu \mathrm{M}$ in a final volume of $200 \mu \mathrm{l}$ for $1 \mathrm{~h}$ at $30^{\circ} \mathrm{C}$. Basal $\left[{ }^{35} \mathrm{~S}\right] \mathrm{GTP} \gamma \mathrm{S}$ binding was defined in the absence of agonist, and non-specific $\left[{ }^{35} \mathrm{~S}\right] \mathrm{GTP} \gamma \mathrm{S}$ binding was defined as binding in the presence of $10 \mu \mathrm{M}$ unlabelled GTP $\gamma$ S. Bound and free $\left[{ }^{35} \mathrm{~S}\right] \mathrm{GTP} \gamma \mathrm{S}$ were separated by vacuum filtration through GF/B glass-fibre filters and quantified by liquid scintillation counting. All experiments were performed in triplicate and done thrice. 
Specific binding was defined as the difference between total binding and non-specific binding (measured in the presence of $10 \mu \mathrm{M}$ naloxone for saturation and competition-binding assays and in the presence of $10 \mu \mathrm{M}$ unlabelled GTP $\gamma \mathrm{S}$ for $\left[{ }^{35} \mathrm{~S}\right] \mathrm{GTP} \gamma \mathrm{S}$ stimulation assays). Data were analysed using the Graph Pad Prism software (Graph Pad, San Diego, CA, USA) and affinity constant $\left(K_{\mathrm{D}}\right)$, receptor density $\left(B_{\max }\right)$, inhibition constant $\left(K_{\mathrm{i}}\right)$ and mean effective dose $\left(\mathrm{EC}_{50}\right)$ values were obtained for each ligand. In saturation-binding assays, data were fit to the non-linear function and to the linear transformation (Scatchard-plot: Bound/Free versus Bound). $K_{\mathrm{i}}$ values were calculated using the correction of Cheng and Prusoff, which corrects for the concentration of radioligand used in each experiment as well as the affinity of the radioligand for its binding site $\left(K_{\mathrm{D}}\right)$.

\section{Results}

\section{Cloning of a $\delta$-opioid-like receptor from zebrafish}

A DNA sequence that codes for the third exon of the mouse $\kappa$-opioid receptor was cloned by RT-PCR using total RNA from mouse brain as template. This fragment, which codes from the first to the fourth transmembrane domains (from nucleotides 448 to 781 of the sequence published by Yasuda et al. 1993), was used as a probe to hybridize a ZIPLOX cDNA library from adult zebrafish brain and a full-length cDNA of $2370 \mathrm{bp}$ was obtained (Fig. 1). The corresponding nucleotide sequence has been deposited under Accession number AY262256. Sequence analysis of this cDNA presents an open reading frame (ORF) of 375 amino acids, with an approximate molecular weight of $42 \cdot 18 \mathrm{kDa}$. The encoded protein shows a high sequence similarity to mammalian $\delta$-opioid receptor (64\% identity to human (Knapp et al. 1994), $63 \%$ to mouse (Evans et al. 1992, Kieffer et al. 1992) and $62 \%$ to rat $\delta$-opioid receptor (Wang et al. 1993)), amphibian homologues $(69 \%$ identity to Taricha granulosa (Bradford et al. 2006) and 68\% to Rana pipiens $\delta$-opioid receptor (Stevens 2004)) and to the other $\delta$-opioid receptor from zebrafish ZFOR1 (71\% identity (Barrallo et al. 1998)). On the other hand, the degree of homology with the mammalian $\mu$-and $\kappa$-opioid receptors only reaches $52 \%$ identity. Hydrophobic analysis reveals that this receptor presents seven potential transmembrane domains, thus confirming that ZFOR4 can be classified as a member of the G-protein-coupled receptor (GPCR) superfamily. Besides, this receptor has two consensus sites for $\mathrm{N}$-glycosylation on the $\mathrm{N}$-terminal extracellular domain (Asn ${ }^{21}$ and $\mathrm{Asn}^{34}$ ), two conserved cysteine residues that can form a disulphide bridge between the first and second extracellular loops (Cys ${ }^{126}$ and $\mathrm{Cys}^{204}$ ), eleven consensus sites for phosphorylation by protein kinase A or C $\left(\mathrm{Ser}^{248}, \mathrm{Ser}^{253}, \mathrm{Ser}^{255}\right.$ and $\mathrm{Thr}^{266}$ in the third intracellular loop, and $\mathrm{Thr}^{344}, \mathrm{Ser}^{350}, \mathrm{Ser}^{352}$, $\mathrm{Ser}^{356}, \mathrm{Ser}^{363}, \mathrm{Ser}^{368}$ and $\mathrm{Ser}^{370}$ in the carboxyl-terminal domain) and a putative palmitoylation site in the C-terminal domain that renders a fourth intracellular loop $\left(\mathrm{Cys}^{339}\right)$.

To determine the genomic structure of ZFOR4, we have used its complete cDNA sequence as a probe to hybridize a zebrafish genomic library (courtesy of B Jones and M Petkovich, Queen's University, Canada). Restriction and sequence analysis showed that ZFOR4 is formed by at least three exons: the first exon comprises the $5^{\prime}$ UTR region and the first $243 \mathrm{bp}$ of the ORF $\left(\mathrm{Met}^{1}-\mathrm{Arg}^{81}\right)$, the second exon contains $357 \mathrm{bp}$ of the coding region $\left(\mathrm{Tyr}^{82}-\mathrm{Gly}^{200}\right)$ and the third exon includes the last $528 \mathrm{bp}$ of the ORF $\left(\mathrm{Lys}^{201}-\mathrm{Thr}^{375}\right.$ ) and the $3^{\prime} \mathrm{UTR}$ region. The genomic organization of the ZFOR4 gene is highly conserved and similar to the one displayed by the mammalian $\delta$-opioid receptors (Augustin et al. 1995).

\section{Expression studies}

The neuroanatomical atlas from Wullimann et al. (1996) has been used for the description of the results. We detect the expression of ZFOR4 specifically localized in the CNS of the zebrafish. Expression is found in all main subdivisions of the brain (telencephalon, diencephalon, mesencephalon and rhombencephalon) and in the spinal cord (Table 1). Specific labelling was observed from rostral to caudal levels, with higher intensity in the hypothalamus (Fig. 2J), periventricular layer of the optic tectum (Fig. 2D and F), granular layer of the cerebellum (Fig. 2G), medium intensity in the dorsal telencephalic areas (Fig. 2A), torus semicircularis (Fig. 2D), reticular formation (Fig. 2I) and facial lobe (Fig. 2H) and with lower intensity in other regions such as the olfactory bulb, thalamus (Fig. 2C) and spinal cord (Table 1). Also, we confirmed the results obtained by our group for the expression of ZFOR1 (Porteros et al. 1999; Fig. 2K).

\section{Pharmacological studies}

To establish the pharmacological profile of ZFOR4, the complete ORF that codes for this receptor was cloned in the mammalian expression vector pcDNA3 and the construct was used to transfect the HEK293 cell line. After obtaining clones that stably express this receptor, membranes were extracted from these cells and radioligand-binding assays were performed. The nonspecific antagonist $\left[{ }^{3} \mathrm{H}\right]$ diprenorphine was used for saturation-binding assays (Fig. 3), displaying one binding site with an affinity constant of $K_{\mathrm{D}}=3 \cdot 42 \pm 0 \cdot 38 \mathrm{nM}$ and a receptor density of $B_{\mathrm{MAX}}=6231 \pm 335 \mathrm{fmol} / \mathrm{mg}$ protein. The specific binding was displaced by naloxone, thus confirming the opioid nature of these sites. 
Table 1 Relative density of ZFOR4 mRNA-labelled cells in the main subdivisions of the zebrafish CNS. Density has arbitrarily been assigned to values as follow: + , low abundance; ++ , moderate abundance; +++ , high abundance; ++++ , very high abundance

ZFOR4

CNS region
I Telencephalon
Olfactory bulb
Dorsal telencephalic area
Ventral telencephalic area
II Diencephalon
Preoptic area
Epithalamus
Dorsal thalamus
Ventral thalamus
Posterior tubercle
Hypothalamus
Synencephalon (NMLF)
Pretectum
III Mesencephalon
Optic tectum
Torus semicircularis
Tegmentum
IV Metencephalon
Valvula cerebelli
Corpus cerebelli
Lobus vestibulolateralis
V Myelencephalon
Octavolateralis area
Reticular formation
Raphe nuclei
Vagal lobe
Glossopharyngeal lobe
Facial lobe
VI Spinal cord
Ventral horn
Dorsal horn

$++$

$++$

$++$

$+++$

$++++$

$+++$

$+++$

$++$

$+++$

$+$

$++$

$+++$

$+++$

$++$

$+++$

$+++$

$++++$

$++$

$+++$

$++$

$++$

$++$

$+++$

$+$

$+$
The $\delta$-selective ligand $\left[{ }^{3} \mathrm{H}\right]$ DPDPE $(\delta)$ has also been used to perform saturation-binding assays on ZFOR4 homogenates, but it did not display any saturable binding (data not shown), hence indicating that this highly selective ligand for mammalian $\delta$ receptors has no affinity for ZFOR4.

To analyse the affinity of different ligands for the ZFOR4 receptor, competition-binding experiments were performed using $\left[{ }^{3} \mathrm{H}\right]$ diprenorphine as radioligand and several unlabelled compounds were used at a concentration range from $0.3 \mathrm{nM}$ to $10 \mu \mathrm{M}$. The results are shown in Fig. 4 and summarized in Table 2. In all cases, the experimental data fitted better to the one-site competition model, as determined by an $F$-test. The ligands tested here can be classified into three categories: (a) the peptidic ligands Met-enkephalin, Leu-enkephalin and dynorphin $\mathrm{A}$ and the non-specific antagonist naloxone, which are able to displace almost all the $\left[{ }^{3} \mathrm{H}\right]$ diprenorphine-specific binding with equilibrium $K_{\mathrm{d}} \mathrm{s}$ ( $K_{\mathrm{i}}$ values) in the nanomolar range. (b) The synthetic $\delta$ agonist BW373U86 and morphine, which cannot totally displace all the specifically bound $\left[{ }^{3} \mathrm{H}\right]$ diprenorphine and whose $K_{\mathrm{i}}$ values are in the micromolar range. (c) The highly selective ligands for mammalian opioid receptors DPDPE $(\delta)$ and U69,593 ( $\kappa)$, which are unable to show an effective displacement.

To confirm if the ZFOR4 receptor is functional, then the agonist activity of several opioid ligands was evaluated using the $\left[{ }^{35} \mathrm{~S}\right] \mathrm{GTP} \gamma \mathrm{S}$ stimulation assay. The maximal $\left[{ }^{35} \mathrm{~S}\right] \mathrm{GTP} \gamma \mathrm{S}$ binding obtained for each ligand when used at a concentration of $10 \mu \mathrm{M}$ is represented in Fig. 5. Our results indicate that the endogenous ligands Met- and Leu-enkephalin and the non-peptidic $\delta$ agonist BW373U86 are able to fully activate this receptor (more than $100 \%$ of the maximal $\left[{ }^{35} \mathrm{~S}\right] \mathrm{GTP} \gamma \mathrm{S}$ stimulation), while D-Ala-D-Leuenkephalin, DSLET and morphine only produce a lower response (around $80 \%\left[{ }^{35} \mathrm{~S}\right] \mathrm{GTP} \gamma \mathrm{S}$ stimulation).

\section{Discussion}

\section{Molecular characterization of ZFOR4}

ZFOR4 is a new opioid receptor from the teleost zebrafish, which can be molecularly classified as a $\delta$-opioid receptor, since it presents a higher degree of homology with the $\delta$ receptors (around 65\% identity) than with the $\mu$ and $\kappa$ receptors ( $52 \%$ identity). This new receptor is a duplicate of another $\delta$ receptor of zebrafish, ZFOR1, which we have previously cloned (Barrallo et al. 1998), as shown in the phylogram presented in Fig. 6 . Both duplicate receptors maintain their opioid activity as demonstrated in our pharmacological characterization. The degree of homology is not uniform along the sequence, as it is higher at the transmembrane domains and at the intracellular and the extracellular loops and amino- and carboxyl-terminus are more divergent (Fig. 7). The first extracellular loop of ZFOR4 is homologous to its mammalian counterparts, since it only has a substitution of the conserved residue $\mathrm{Glu}^{112}$ by a Gly ${ }^{117}$. Remarkably, this glycine is also present in the same position in the $\mu$ and ORL receptors $\left(\mathrm{Gly}^{133}\right.$ and $\mathrm{Gly}^{113}$ in the human $\delta$ and ORL receptors respectively). Nevertheless, it seems that the change of Glu ${ }^{112}$ Gly in the $\delta$-opioid receptors does not affect the ability of different ligands to bind to these receptors (Fukuda et al. 1995).

The second and third extracellular loops are involved in the selective binding of different ligands to the opioid receptors (Metzger \& Ferguson 1995). The second extracellular loop of ZFOR4 possesses more positive and negative charges than its counterparts in the mammalian and amphibian $\delta$ receptors, which can explain why the highly selective $\delta$ ligands show lower or no affinity for ZFOR4. The third extracellular loop is the least homologous, exhibiting significant changes in charge and amino acid size or hydrophobicity. 

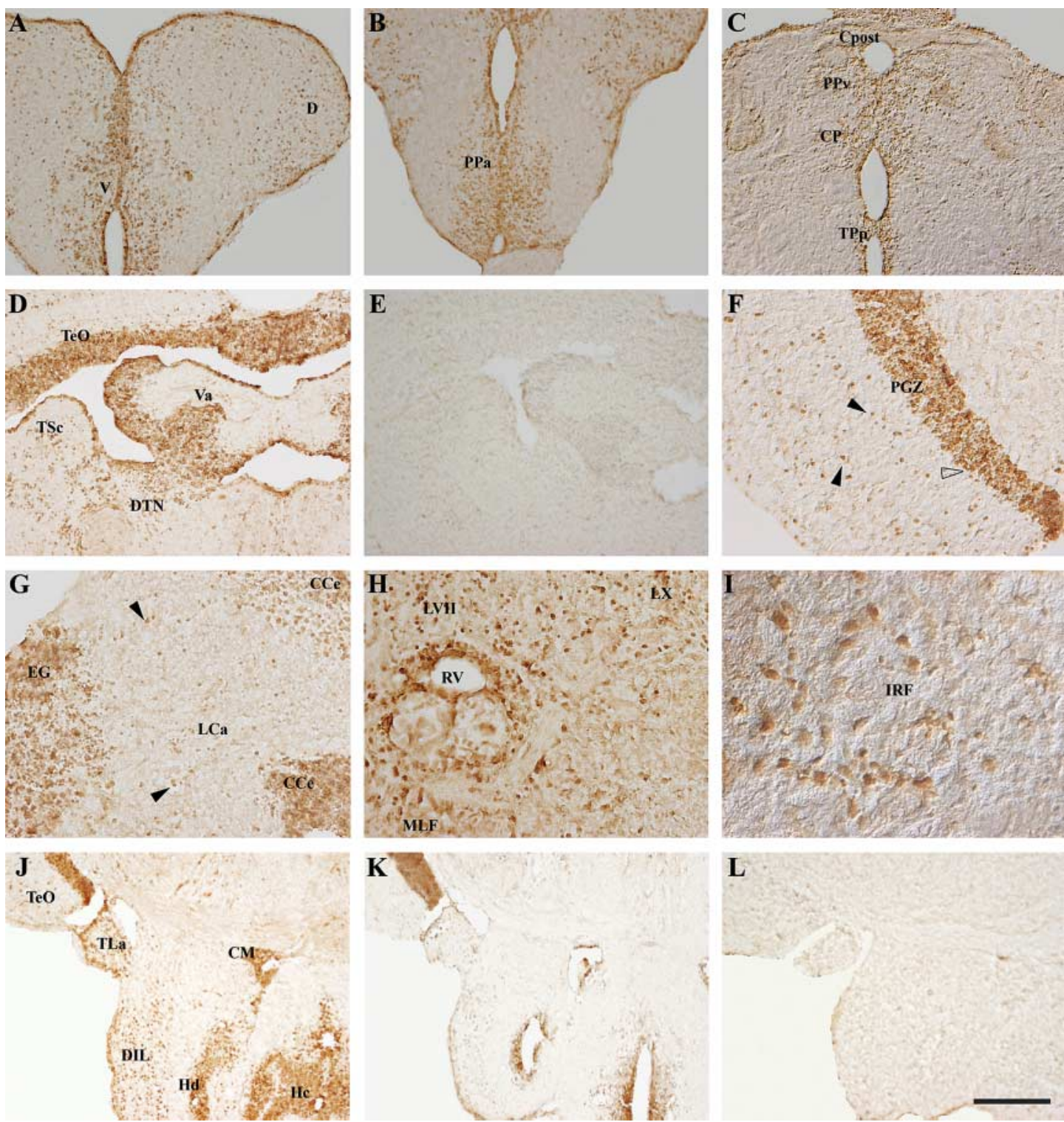

Figure 2 Localization of ZFOR4 mRNA expression by in situ hybridization in the adult zebrafish brain (coronal sections) (A-I). (A) Telencephalon ( $\mathrm{D}$, dorsal telencephalic area; $\mathrm{V}$, ventral telencephalic area), (B) anterior diencephalon (PPa, anterior part of the parvocellular preoptic nucleus, (C) diencephalon (Nomarski micrograph; CP, central posterior thalamic nucleus; Cpost, commissura posterior; PPv, ventral part of the periventricular pretectal nucleus; TPp, periventricular nucleus of posterior tuberculum), (D) mesenchepalon (DTN, dorsal tegmental nucleus; TeO, optic tectum; TSc, central nucleus of the torus semicircularis; Va, valvula cerebelli), (E) a coronal section at the same level, close to D, processed for negative control, does not show any labelling, (F) optic tectum (Nomarski micrograph). High density of cells was observed in the periventricular layer (open arrow) and scarce cells with different morphologies were observed in other strata (filled arrows), (G) metencephalon. Abundant cells were labelled in the eminentia granularis (EG) and corpus cerebelli (CCe) and scarce cells (arrows) were also observed in the caudal lobe of the cerebellum (LCa), $(\mathrm{H})$ myelencephalon (MLF, medial longitudinal fascicle; LVII, facial lobe; LX, vagal lobe; RV, rhombencephalic ventricle), (I) high magnification of labelled cells in the inferior reticular formation (IRF), showing the variety of sizes and shapes of positive cells. (Nomarski micrograph). (J-L) Coronal sections of adult zebrafish brain showing the comparative in situ hybridization signal expression for both $\delta$-opioid-like receptors from zebrafish, (J) ZFOR4 and (K) ZFOR1 in the ventral mesencephalon. (L) Absence of signal is shown at the same level, close to $A$ and $B$, processed for negative control. It can be observed that the expression for ZFOR4 is more widespread and the number of positive cells is greater than that observed for ZFOR1 (Porteros et al. 1999). Abbreviations: CM, corpus mamilare; DIL, diffuse nucleus of the hypothalamic inferior lobe; Hc, caudal zone of the hypothalamic periventricular nucleus; $\mathrm{Hd}$, dorsal zone of the hypothalamic periventricular nucleus; TeO, optic tectum; TLa, torus lateralis. Scale bar: $50 \mu \mathrm{m}$ in I; $100 \mu \mathrm{m}$ for F, G and H; $200 \mu \mathrm{m}$ for A-E and J-L. 


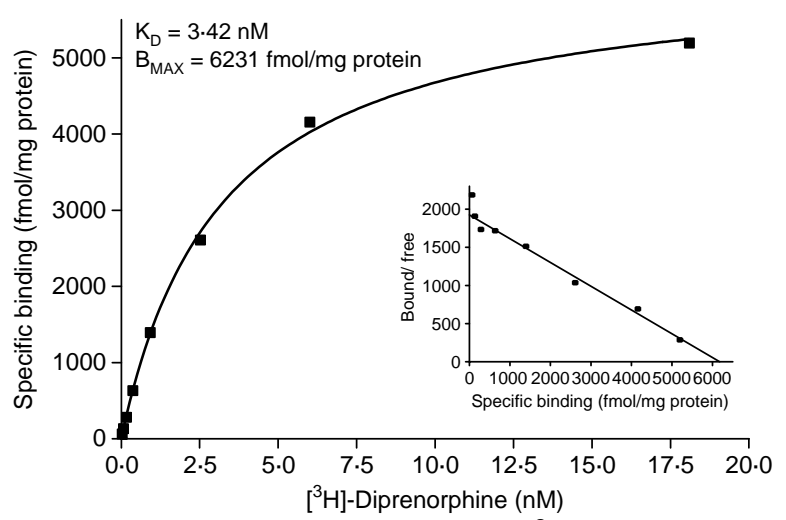

Figure 3 Saturation-binding assays of $\left[{ }^{3} \mathrm{H}\right]$ diprenorphine in membrane homogenates from stably transfected HEK293 cells expressing ZFOR4. Inset: Scatchard-plot. Results are from a representative experiment performed in duplicate and repeated thrice.

Although the $\mathrm{Val}^{302}$ and $\mathrm{Val}^{303}$ are conserved in the same positions as in the mammalian receptors $\left(\mathrm{Val}^{296}\right.$ and $\mathrm{Val}^{297}$ ), the $\operatorname{Trp}^{284}$ is replaced by Lys ${ }^{290}$, which plays a crucial role for the binding of DPDPE and deltorphin (Valiquette et al. 1996). Also, instead of the $\mathrm{Arg}^{291}$ and $\mathrm{Arg}^{292}$ of the mammalian $\delta$ receptors, ZFOR4 presents a $\mathrm{Gln}^{297}$ and $\mathrm{Lys}^{298}$, which together with the existence of a $\operatorname{Trp}^{306}$, can explain the loss of affinity for the highly selective ligands for the mammalian $\delta$ receptors (Wang et al. 1995, Pepin et al. 1997).

Although the two $\delta$-opioid receptors from zebrafish are homologues with high sequence similarity, they present some divergences in their amino acid sequences that can explain the pharmacological differences. The second extracellular loop of ZFOR4 has more charged residues than ZFOR1, which means that this loop from ZFOR resembles more than the ones from the mammalian $\delta$ receptors. Some exceptions are the conserved Asp ${ }^{198}$ in ZFOR4 (equivalent to Asp ${ }^{193}$ in mammalian receptors), which is substituted by $\mathrm{Asn}^{196}$ in ZFOR1, and the Gly ${ }^{200}$ in ZFOR4 (equal to Gly ${ }^{194}$ in mammals) that is replaced by Asn ${ }^{198}$, a bulky residue, in ZFOR1. The third extracellular loops of ZFOR1 and ZFOR4 are quite similar among themselves, but as we have described previously, they differ significantly from the ones of the mammalian $\delta$ receptors. However, there are some substitutions in one of these two duplicate receptors: the conserved Pro ${ }^{294}$ in the mammalian receptors and in ZFOR1 $\left(\right.$ Pro $^{298}$ ) is replaced by $\mathrm{Leu}^{300}$ in ZFOR4, and conversely, the conserved Leu ${ }^{295}$ in the mammalian receptors and in ZFOR4 $\left(\mathrm{Leu}^{301}\right)$ is exchanged by Phe ${ }^{299}$ in ZFOR1.

\section{Expression studies}

We have analysed the distribution of ZFOR4 in the zebrafish CNS by means of non-radioactive in situ hybridization using specific oligonucleotides labelled with digoxigenin at its $5^{\prime}$ end. We have detected specific signal in the same regions, where ZFOR1 (Porteros et al. 1999) was found to be expressed in the CNS of the zebrafish (Table 1), but the signal is less intense in this case although most of the structures that show expression, such as dorsal telencephalic areas (D; Fig. 2A), hypothalamus (Fig. 2J and K), granular layer of the cerebellum (Fig. 2G), reticular formation (Fig. 2I) and facial lobe (Fig. 2H) present a greater number of positive cells.

The distribution of $\delta$-opioid receptors in fish has been described from binding data (Bird et al. 1988) and by in situ hybridization in the case of ZFOR1, the duplicate gene previously described by us (Barrallo et al. 1998). In mammals, the distribution of $\delta$-opioid receptor mRNA (Mansour et al. 1994) shows this receptor being abundant in olfactory bulb, neocortex, striatum, hippocampus, amygdala, pontine nuclei and dorsal horn of the spinal cord, what has been related to analgesia, gastrointestinal motility and hypothalamic
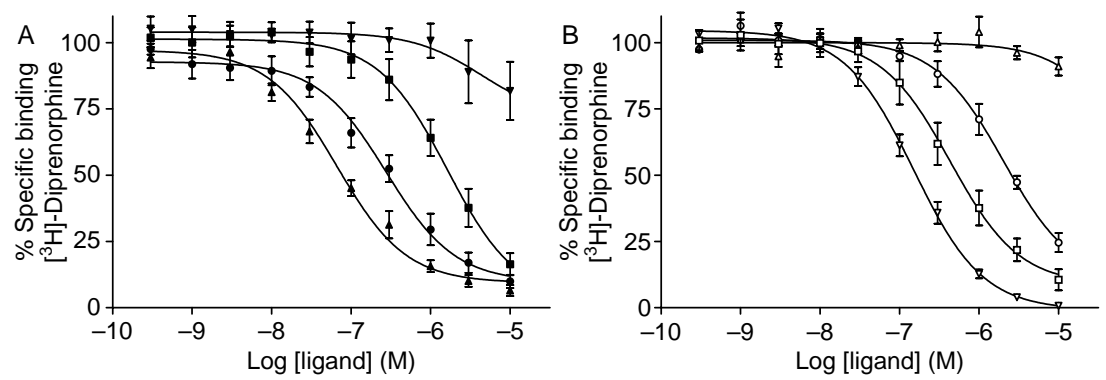

Figure 4 Competition-binding assays of $\left[{ }^{3} \mathrm{H}\right]$ diprenorphine and several unlabelled ligands using membrane homogenates from stably transfected HEK293 cells expressing ZFOR4. (A) Unlabelled ligands which are $\delta$-selective. (B) Unlabelled ligands that are not $\delta$-selective. Results represent the mean \pm S.E.M. of three independent experiments performed in duplicate. Non-specific binding was determined using $10 \mu \mathrm{M}$ naloxone. Legend: BW373U86; $\boldsymbol{\Delta}$, Met-enkephalin; $\boldsymbol{\bullet}$, Leu-enkephalin; $\boldsymbol{\nabla}$, DPDPE; $\square$ dynorphin A; $\triangle$, U69,593; $\nabla$, naloxone; $\bigcirc$, morphine. 
Table $2 K_{\mathrm{i}}$ values of several ligands in ZFOR4 obtained from competition-binding assays using [ ${ }^{3} \mathrm{H}$ ]diprenorphine. Values represent mean \pm S.E.M. from three experiments performed in duplicate

$\boldsymbol{K}_{\mathbf{i}}(\mathrm{nM})$

$\%$ Displacement ${ }^{\mathrm{a}}$

$K_{\mathrm{i}}(\mathrm{nM})$ for mammalian DoR

Ligand

BW373U86

$1020 \cdot 53 \pm 377 \cdot 74$

$83 \cdot 58 \pm 4 \cdot 17$

Met-enkephalin

$45 \cdot 77 \pm 9 \cdot 62$

$93 \cdot 49 \pm 2 \cdot 06$

Leu-enkephalin

$175 \cdot 20 \pm 69 \cdot 45$

$90 \cdot 08 \pm 2 \cdot 49$

DPDPE

$$
>10000
$$

Dynorphin A

$343 \cdot 47 \pm 114 \cdot 12$

$18 \cdot 67 \pm 10 \cdot 97$

$89 \cdot 45 \pm 3.98$

U69,593

Naloxone

$$
>10000
$$

$88 \cdot 29 \pm 13.33$

$8.94 \pm 3.42$

$99 \cdot 22 \pm 0 \cdot 24$

Morphine

$1427 \cdot 67 \pm 302 \cdot 44 \quad 75 \cdot 40 \pm 3 \cdot 60$
$0.16 \pm 0.02$ (Meng et al. 1996)

1.63 (Befort et al. 1996)

$3.0 \pm 1.8$ (Meng et al. 1996)

5.01 (Befort et al. 1996)

$1.80+0.5$ (Mansour et al. 1995)

$4 \cdot 2 \pm 2 \cdot 4$ (Meng et al. 1996)

6.52 (Befort et al. 1996)

$6 \cdot 19 \pm 1.00$ (Mansour et al. 1995)

$21 \pm 4$ (Meng et al. 1996)

$31 \cdot 7$ (Befort et al. 1996)

21.6 (Befort et al. 1996)

$1 \cdot 25 \pm 0 \cdot 12$ (Zhang et al. 1998)

$2 \cdot 64 \pm 0.35$ (Mansour et al. 1995)

30.6 (Befort et al. 1996)

$44 \cdot 8 \pm 5 \cdot 8$ (Chaturvedi et al. 2000)

$0.92 \pm 0.21$ (Mansour et al. 1995)

$249 \cdot 7 \pm 41 \cdot 4$ (Chaturvedi et al. 2000)

$7 \cdot 48 \pm 0.59$ (Mansour et al. 1995)
$K_{\mathrm{i}}(\mathrm{nM})$ for ZFOR1 $K_{\mathrm{i}}(\mathrm{nM})$ for amphibian (Rodriguez et al. DOR (Bradford et al. 2000) 2006)

24.9

198

953

499

$>10000$

$53 \cdot 8$

$>10000$

$3 \cdot 32$

223

${ }^{\text {aP }}$ ercentage of displacement of $\left[{ }^{3} \mathrm{H}\right]$ diprenorphine shown at a concentration of $10 \mu \mathrm{M}$ of the unlabelled ligand.

regulation. In our case, the abundant ZFOR4 mRNA immunostained cells observed through the inferior hypothalamic lobes and in the periventricular grey of zebrafish lateral recesses (Fig. 2J) could be related with an opioid modulation of visuomotor activities related to prey catching and feeding responses in zebrafish brain. Indeed, electrical stimulation of these hypothalamic areas has been demonstrated in fish (Demski 1973) to elicit feeding, picking up of gravel and aggressive behaviours. On the other hand, although there is evidence that morphine has a modulatory effect in the corticotrophin-releasing activity in fish (Bird et al. 1987, Mukherjee et al. 1987) and that the opioid peptides interact with the neuroendocrine system of mammals (Grossman \& Rees 1983), the involvement of $\delta$-opioid receptor in the modulation of hormone release from the hypothalamic-hypophysary axis seems to be of minor importance in mammals (Mansour et al. 1993), although it has also been demonstrated that endogenous opioids, such as $\beta$-endorphin, exert a tonic restraint on gonadotrophin-releasing hormone $(\mathrm{GnRH})$ secretion (Pu et al. 1997). In teleosts, regional distribution and in vitro secretion of GnRH from the brain and pituitary of goldfish (Carassius auratus) has also been studied (Rosenblum et al. 1994). Indeed, the expression of these $\delta$-opioid receptors from zebrafish, found in neuroendocrine regions, including preoptic area (Fig. 2A) and the hypothalamus (Fig. 2J and K) is likely involved in control of GnRH and luteinizing hormone (LH) release. In this sense, the presence and distribution of a $\delta$-opioid receptor population on a subset of hypothalamic GnRH neurons in the mouse has recently been demonstrated (Pimpinelli et al. 2006).

In the reticular formation of mammals, $\delta$-opioid receptors are involved in analgesic mechanisms (Mansour et al. 1993), as might be in teleosts, due to the presence of ZFOR4 and ZFOR1 mRNAs in the whole rostrocaudal extension of the reticular formation (Fig. 1I). ZFOR4 mRNA expression has been detected

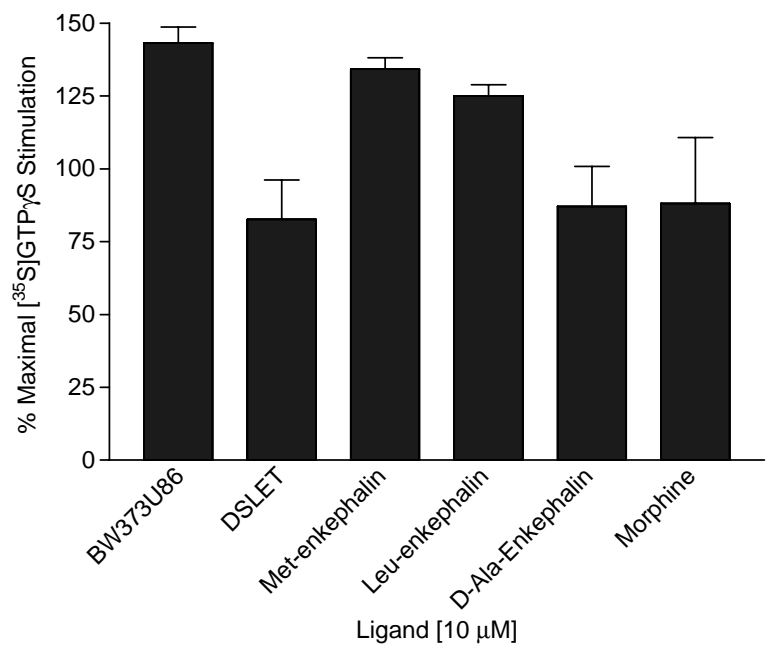

Figure 5 Stimulation of $\left[{ }^{35} \mathrm{~S}\right] \mathrm{GTP} \gamma \mathrm{S}$ binding to ZFOR4 membrane homogenates by various ligands at a concentration of $10 \mu \mathrm{M}$. Non-specific binding was determined with $10 \mu \mathrm{M}$ GTP $\gamma \mathrm{S}$. Values represent the mean \pm S.E.M. of three independent experiments performed in triplicate. 


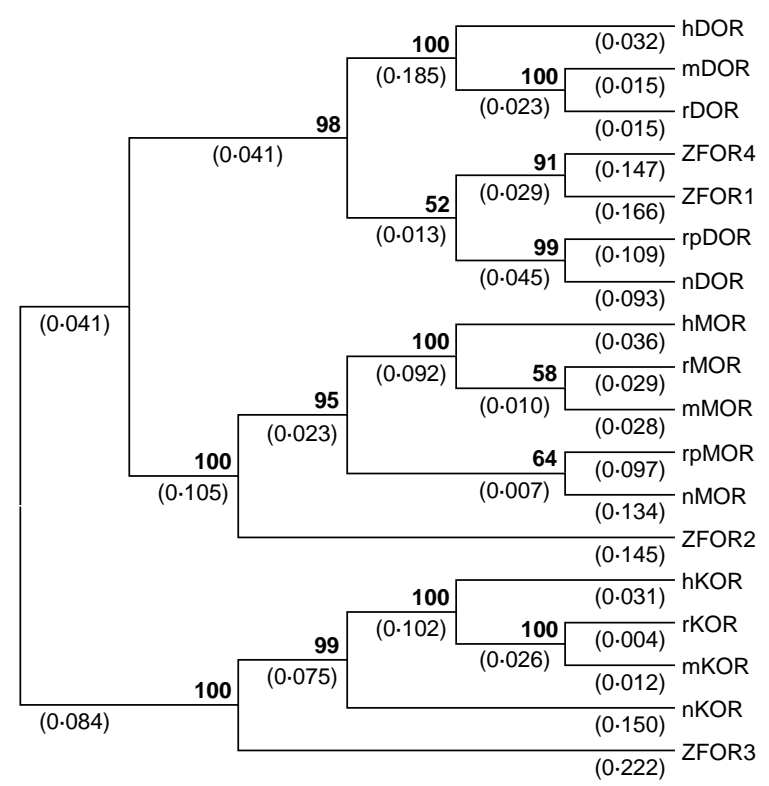

Figure 6 Phylogram generated by neighbour joining method, from the alignment of the deduced amino acid sequences of the opioid receptors from zebrafish and its homologues identified in mammals and in amphibians. This analysis was conducted using MEGA version 2.1 (Kumar et al. 2001). Whole numbers (bold) indicate bootstrap values and branch distances are given in decimal numbers. Sequences were obtained from GenBank. Accession numbers are: hDOR (Homo sapiens), U10504; mDOR (Mus musculus), L06322; rDOR (Rattus norvegicus),

NM_012617; ZFOR1 (Danio rerio), NM_131258; ZFOR4, AY262256; rpDOR (Rana pipiens), AF530572; nDOR (Taricha granulosa), AY751785; hMOR, NM_000914; mMOR, U10558.1; rMOR, NM 013071.1; ZFOR2, AF132813; rpMOR, AY244471; nMOR, AY75178; hKOR, NM_000912.3; mKOR, NM_011011.1; rKOR, NM_017167.1; ZFOR3, AF285173; nKOR, AF285173.

in dorsal and ventral horns of the spinal cord of zebrafish, although to a lesser extent that was reported for ZFOR1 (Porteros et al. 1999) and similar to that previously reported in mammals, where $\delta$-opioid receptor binding and mRNA expression have been observed in scattered cells on several laminae of ventral and dorsal horns (Mansour et al. 1993).

The occurrence of moderate expression of ZFOR4 mRNA in areas, such as the pretectum and posterior tuberculum, which are sensory-motor integrative centres very well developed in teleosts (Meek \& Nieuwenhuys 1998), suggests that the $\delta$-opioid system might be influenced, at least in lower vertebrates, by adaptive mechanisms also related to behavioural responses basic for survival. Also, even when there are evolutive differences between the CNS of mammals and fish (Butler \& Hodos 1996), some homologies have been proposed, such as the dorsal telencephalic areas in fish with the cerebral cortex and basal ganglia and the cerebellum, which suggests that if there is correspondence inthe distribution then it could also exist as a comparative evolution in the function.

\section{Pharmacological profile of the ZFOR4 receptor}

The binding studies allowed us to determine the pharmacological profile of ZFOR4 receptor and to compare it with those established for the $\delta$ receptors in other species as well as with its duplicate in zebrafish ZFOR1. The non-specific antagonist $\left[{ }^{3} \mathrm{H}\right]$ diprenorphine binds to ZFOR4 with high affinity, and this binding can be displaced by naloxone, hence confirming the opioid nature of this receptor. The affinity constant $\left(K_{\mathrm{D}}=3 \cdot 42 \pm\right.$ $0.38 \mathrm{nM})$ is in the same range to that previously observed for ZFOR1 $\left(K_{\mathrm{D}}=3.4 \pm 0.6 \mathrm{nM}\right)$ by us (Rodriguez et al. $2000)$, and slightly higher, although in the same order, than those reported for the human $\delta$ receptor $\left(K_{\mathrm{D}}=\right.$ $1.48 \pm 0.8 \mathrm{nM}$ (Varga et al. 1996), $K_{\mathrm{D}}=1.8 \pm 0.4 \mathrm{nM}$ (Zhang et al. 1998) and $K_{\mathrm{D}}=0 \cdot 75 \pm 0.07 \mathrm{nM}$ (Cavalli et $a l .1999))$. On the other hand, the $\delta$-selective radioligand $\left[{ }^{3} \mathrm{H}\right]$ DPDPE for the mammalian $\delta$ receptors $\left(K_{\mathrm{D}}=6 \mathrm{nM}\right.$ (Mansour et al. 1995) and $K_{\mathrm{D}}=3 \cdot 1 \pm 0 \cdot 3 \mathrm{nM}$ (Pepin et al. 1997)) does not bind to ZFOR4, and with very low affinity to ZFOR1 ( $K_{\mathrm{i}}=953 \mathrm{nM}$; Rodriguez et al. 2000). The fact that the $\delta$-opioid receptor of the newt presents a $K_{\mathrm{i}}=$ $499 \mathrm{nM}$ for DPDPE (Bradford et al. 2006), which is an intermediate value between those established for the mammalian and zebrafish $\delta$ receptors, indicates that the DPDPE selectivity is gradually lost when moving down in the evolutionary scale and suggests that this ligand may not be suitable for determining the $\delta$-binding profile in such organisms.

To determine the affinity of different compounds for ZFOR4 receptor, we have performed competition-binding assays using $\left[{ }^{3} \mathrm{H}\right]$ diprenorphine as the radioligand. The specific binding was displaced by several unlabelled ligands, some of them are $\delta$ selective (DPDPE, BW373U86), $\kappa$ selective (U69,593), non-selective (naloxone), endogenous peptides (Met-enkephalin, Leu-enkephalin, Dynorphin A) and non-endogenous compounds (morphine). Met-enkephalin, naloxone and Leu-enkephalin are good displacers, since their $K_{\mathrm{i}}$ values are in the nanomolar range and able to displace almost all the specific binding, while dynorphin A, BW373U86 and morphine present lower affinities $\left(K_{\mathrm{i}}\right.$ values near or in the micromolar range) and only displace about 80-90\%, and lastly DPDPE and U69,593 are not able to displace more than $20 \%$ of the specifically bound $\left[{ }^{3} \mathrm{H}\right]$ diprenorphine. These values obtained for ZFOR4 are higher than the ones reported for mammalian $\delta$ receptors (see Table 2), with the less significant differences found for the endogenous peptides and naloxone. Nevertheless, it is important to consider that some of the $K_{\mathrm{i}}$ values reported for the mammalian $\delta$ receptors have been obtained using other radioligands different from $\left[{ }^{3} \mathrm{H}\right]$ diprenorphine, such as $\left[{ }^{3} \mathrm{H}\right]$ etylketocyzaclozine (Meng et al. 1996), bremazocine (Meng et al. 1996, Chaturvedi et al. 2000) and $\left[{ }^{3} \mathrm{H}\right] \mathrm{DPDPE}$ (Mansour et al. 1995), that may recognize different 
Homo sapiens Mus musculus Rattus norvegicus Taricha granulosa Rana pipiens Danio rerio ZFOR1 Danio rerio ZFOR4

Homo sapiens Mus musculus Rattus norvegicus Taricha granulosa Rana pipiens Danio rerio ZFOR1 Danio rerio ZFOR4

Homo sapiens Mus musculus Rattus norvegicus Taricha granulosa Rana pipiens Danio rerio ZFOR1 Danio rerio ZFOR4

Homo sapiens Mus musculus Rattus norvegicus Taricha granulosa Rana pipiens Danio rerio ZFOR1 Danio rerio ZFOR4

Homo sapiens Mus musculus Rattus norvegicus Taricha granulosa Rana pipiens Danio rerio ZFOR1 Danio rerio ZFOR4

Homo sapiens Mus musculus Rattus norvegicus Taricha granulosa Rana pipiens

Danio rerio ZFOR1 Danio rerio ZFOR4

Homo sapiens Mus musculus Rattus norvegicus Taricha granulosa Rana pipiens Danio rerio ZFOR1 Danio rerio ZFOR4
N-Terminus

MEPAPSAGA---ELQPPLFANAS-DAYPSACPSAGANASGPPG--ARSASSLALAIAITA 54 MELVPSARA---ELQSSPLVNLS-DAFPSAFPSAGANASGSPG--ARSASSLALAIAITA 54 MEPVPSARA---ELQFSLLANVS-DTFPSAFPSASANASGSPG--ARSASSLALAIAITA 54 MELSTMSGA---GLYPDFLFYN--ATS-FNENGSLNETRPFP---VKNITSIVIAIAITA 51 MEL-ELSTS---RLYSDILFYN--ATQNLSESPTSNSSFSVPGQVSRNHAS I IMAVAITA 54 MEPSVIPGADIPDLYS INPFNVTFPDDVLSFVPDGRN-YTEPN-PVK-SRGIIIAISITA 57 MEPPTVTVSDFSERYPLFLHNSSFLEEPAGLLSNWSGGSSELK-AVRGSSAVAIAVSITA 59

$$
\text { TM I }
$$$$
\text { IL I }
$$

TM II

LYSAVCAVGLLGNVLVMFGIVRYTKMKTATNIYIFNLALADALATSTLPFOSAKKYLMETW 114 LYSAVCAVGLLGNVLVMFGIVRYTKLKTATNIYIFNLALADALATSTLPFQSAKYLMETW 114 LYSAVCAVGLLGNVLVMFGIVRYTKLKTATNIYIFNLALADALATSTLPFQSAKYLMETW 114 LYSVVCVVGLLGNILVMYGIVRYTKMKTATNIYIFNLALADALATSTLPFOSAKYLMETW 111 LYSVVCVVGLLGNILVMYGIVRYTKMKTATNIYIFNLALADALATSTLPFQSAKYLMETW 114 LYSVICVVGLLGNILVMYGVVRYTKLKTATNIYIFNLALADALATSTLPFQSTKYLMNTW 117 LYSVICVVGLVGNVLVMYGVVRYTKMKTATNIYIFNLALADALATSTLPFOSAKYLMGTW 119

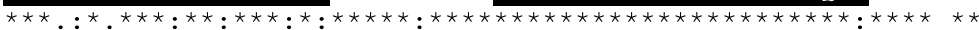
EL I
TM III
II II

PFGELLCKAVLSIDYYNMFTSIFTLTMMSVDRYIAVCHPVKALDFRTPAKAKLINICIWV 174 PFGELLCKAVLSIDYYNMFTSIFTLTMMSVDRY IAVCH PVKALDFRTPAKAKLINICIWV 174 PFGELLCKAVLSIDYYNMETSIFTLTMMSVDRY IAVCHPVKALDFRTPAKAKLINICIWV 174 PFGELLCKVVLSIDYYNMETSIFTLTMMSVDRYVAVCHPVRALDFRTPVKAKI INVCIWI 171 PFGEVLCKVVLSIDYYNMFTSIFTLTMMSVDRYVAVCHPVRALDFRTPSKAKAVNVCIWI 174 PFGELLCKVVIAIDYYNMFTSIFTLTMMSVDRYIAVCHPVRALEFRTP IKAKIINVCIWI 177 PEGELLCKVVIAIDYYNMFTSIFTLTMMSVDRYIAVCHPVRALDFRT PVKAKIINICVWI 179

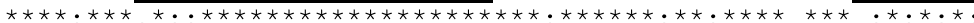

TM IV

EL II

TM V

LASGVGVPIMVMAVTRPRD-GAVVCMLQFPS PSWYWDTVTKICVFLFAEVVPILIITVCY 233 IASGVGVPIMVMAVTQPRD-GAVVCMLQFPSPSWYWDTVTKICVFLFAFVVPILIITVCY 233 LASGVGVPIMVMAVTQPRD-GAVVCTLQFPSPSWYWDTVTKICVFLFAFVVPILIITVCY 233 LSSI IGVPIMVMAVTKTDKA GTTYCTLQFP GPEGYWDTVTKICVFIFAFLVPVLVITICY 231 LSSI IGVPIMVMAVTKTNKAGT I TCMLQF PRP DWYWDTVTKICVFIFAFVIPVMVITVCY 234 LSSAVGVPIMIMAVTRVTNQNTTVCMLKFPDPDWYWDTVTKICVFIFAFVVPVLVITICY 237

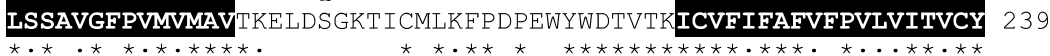

IL III

TM VI

EL III

GLMLLRLRSVRLLSGSKEKDRS LRRI TRMVLVVVGAFVVCWAPIHIFVIVWTLVDIDRRD 293 GLMLLRLRSVRLLSGSKEKDRS LRRI TRMVLVVVGAFVVCWAPIHIFVIVWTLVDINRRD 293 GLMLLRLRSVRLLSGSKEKDRSLRRITRMVLVVVGAFVVCWAPIHIFVIVWTLVDINRRD 293 GLMILRLKSVRLLSGSKEKDRNMRR I TRMVLVVVAAFI ICWTPIHIFVIVWTMVDIDKKN 291 GLMILRLRSVRLLSGSREKDRNLRRITRMVLVVVAAFI ICKTPIHIFVIVWTMVEIDKRN 294 GLMILRLKSVRLLSGSKEKDRNMRRI TRMVLVVVAAFIICWTPIHIFIIEKTLVDINQKN 297 GLMILRLKSVRLLSGSKEKDRNLRRITRMVLVVVAAFIICWTPIHIFIIVKTVVEIDQKN 299

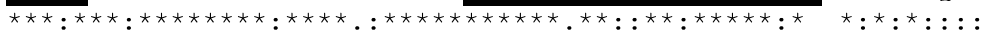

TM VII C-Terminus

PLVVAALHLCIALGYANSSLNPVLYAFIDENFKRCFRQLCRKPCGRPDPSSFSRAREATA 353 PLVVAALHLCIALGYANSSLNPVLYAFLDENFKRCFRQLCRT PCGRQEPGSLRRPRQATT 353 PLVVAALHLCIALGYANSSLNPVLYAFLDENFKRCFRQLCRAPCGGQE PGSLRRPRQATA 353 PFVIASWHFCIALGYTNSSLNPVLYAFLDENFKRCFRDFCLPFRARMEQSSFTRAK-NAT 350 PYVVASWHFCIALGYTNSSLNPVLYAFLDENFKRCFREFCLPFRTHAEQSSFSRAR-NTT 353 PFVIASWHLHRT-GYTNSSLNPVLYAFLDENFKRCFRDFCLPFRTRADQSNLNRAR-NAT 355 LLVVACWHLCIALGYMNSSLNPVLYAFLDENFKRCFREFCLPERTRIEQNSFSKAR-SVI 358

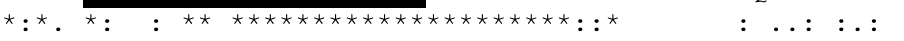

Figure 7 Alignment produced with ClustalW program of the deduced amino acid sequences for the $\delta$-opioid receptors from human (Accession number U10504), mouse (L06322), rat (NM_012617), the amphibians newt (AY751785) and frog (AF530572) and the $\delta$-opioid receptors from zebrafish ZFOR1 (NM_131258) and ZFOR4 (AY262256). The transmembrane regions are shaded. Legends: *, identical residues in all of the sequences; :, conserved residues;.., similar residues. 
moieties in the receptor-binding pocket and thus displaying different displacement curves for the unlabelled compounds. When the displacement results for ZFOR4 are compared with those seen for the amphibian $\delta$ receptor (Bradford et al. 2006), the $K_{\mathrm{i}}$ values are comparable, except for naloxone, which is also the radioligand used by these authors. The study of the competition-binding results of ZFOR1 and ZFOR4 indicates that the $K_{\mathrm{i}}$ values are similar when the same unlabelled ligand is used, with the exception of morphine, which is a better displacer in ZFOR1 than in ZFOR4.

To determine if ZFOR4 is functional, we have used the $\left[{ }^{35} \mathrm{~S}\right] \mathrm{GTP} \gamma \mathrm{S}$-binding assay to evaluate the effect of different agonists to activate the G-proteins through this receptor. All the ligands used in this test were able to activate ZFOR4 and transduce the signal to the G-proteins, although with different maximal effect. The non-peptidic $\delta$ ligand BW373U86 and the endogenous Met- and Leu-enkephalins showed more than $100 \%$ stimulation of $\left[{ }^{35} \mathrm{~S}\right] \mathrm{GTP} \gamma \mathrm{S}$ binding to membranes from ZFOR4 expressing HEK293 cells, while in experiments using $\left[\mathrm{D}-\mathrm{Ser}^{2}, \mathrm{Leu}^{5}{ }^{5}\right.$ enkephalin-Thr ${ }^{6}$ (DSLET), D-Ala-D-Leuenkephalin and morphine $\left[{ }^{35} \mathrm{~S}\right] \mathrm{GTP} \gamma \mathrm{S}$ stimulation only reached $80 \%$, thus behaving as partial agonists. Interestingly, similar results have been found with its duplicate ZFOR1, where BW373U86 fully activates the receptor and morphine is also behaving as a partial agonist on the $\left[{ }^{35} \mathrm{~S}\right]$ GTP $\gamma$ S-binding assay (Rodriguez et al. 2000).

Taking into consideration the results obtained from the pharmacological studies of ZFOR4, we can conclude that, as seen in ZFOR1, the non-selective ligands as well as the endogenous peptides can bind to the receptor-binding pocket with high affinity, while the highly selective ligands designed for the mammalian opioid receptors are not recognized by the determinants of selectivity in ZFOR4 receptor. Our findings agree with the hypothesis that the opioid receptor-binding pocket that contains the essential moieties for ligand binding is well conserved through vertebrate evolution, but the structural features implicated in ligand selectivity, mainly located in the second and third extracellular loops (Metzger \& Ferguson 1995, Meng et al. 1996, Varga et al. 1996), have gradually evolved. As a result, this process gave rise to the different opioid receptor types with differential-binding profile between types and among one type (namely $\mu, \delta$ or $\kappa$ ) in the distinct vertebrate species. The presence of two genes that code for $\delta$-opioid receptors (ZFOR1 and ZFOR4) in the zebrafish could be the outcome of an extra duplication that took place in teleosts.

\section{Acknowledgements}

This study was supported by grants from Ministerio de Educación y Ciencia (SAF2004-05144) and Junta de Castilla y León (SA080A05). The authors declare that there is no conflict of interest that would prejudice the impartiality of this scientific work.

\section{References}

Augustin LB, Felsheim RF, Min BH, Fuchs SM, Fuchs JA \& Loh HH 1995 Genomic structure of the mouse $\delta$ opioid receptor gene. Biochemical and Biophysical Research Communications 207 111-119.

Barrallo A, Gonzalez-Sarmiento R, Porteros A, Garcia-Isidoro M \& Rodriguez RE 1998 Cloning, molecular characterization, and distribution of a gene homologous to delta opioid receptor from zebrafish (Danio rerio). Biochemical and Biophysical Research Communications 245 544-548.

Barrallo A, Gonzalez-Sarmiento R, Alvar F \& Rodríguez RE 2000 ZFOR2, a new opioid receptor-like gene from the teleost zebrafish (Danio rerio). Molecular Brain Research 84 1-6.

Befort K, Tabbara L, Kling D, Maigret B \& Kieffer BL 1996 Role of aromatic transmembrane residues of the $\delta$-opioid receptor in ligand recognition. Journal of Biological Chemistry 271 10161-10168.

Bird DJ, Buckingham JC, Baker BI \& Mukherjee S 1987 Hypothalamopituitary-interrenal responses to opioid substances in the trout. I. Effects of morphine on the release in vitro of corticotrophinreleasing activity from the hypothalamus and corticotrophin from the pituitary gland. General and Comparative Endocrinology 68 33-39.

Bird DJ, Jackson M, Baker BI \& Buckingham JC 1988 Opioid binding sites in the fish brain: an autoradiographic study. General and Comparative Endocrinology 70 49-62.

Bradford CS, Walthers EA, Stanley DJ, Baugh MM \& Moore FL 2006 Delta and mu opioid receptors from the brain of a urodele amphibian, the rough-skinned newt Taricha granulosa: cloning, heterologous expression, and pharmacological characterization. General and Comparative Endocrinology 146 275-290.

Butler AB \& Hodos W 1996. Comparative Vertebrate Neuroanatomy: Evolution and Adaptation, New York: Wiley-Liss.

Cavalli A, Babey AM \& Loh HH 1999 Altered adenylyl cyclase responsiveness subsequent to point mutations of Asp 128 in the third transmembrane domain of the delta-opioid receptor. Neuroscience 93 1025-1031.

Chaturvedi K, Jiang X, Christoffers KH, Chinen N, Bandari P, Raveglia LF, Ronzani S, Dondio G \& Howells RD 2000 Pharmacological profiles of selective non-peptidic $\delta$ opioid receptor ligands. Molecular Brain Research 80 166-176.

Craft RM, Ulibarri CM \& Raub DJ 2000 Kappa opioid-induced duresis in female vs. male rats. Pharmacology, Biochemistry and Behavior 65 53-59.

Darland T \& Dowling JE 2001 Behavioral screening for cocaine sensitivity in mutagenized zebrafish. PNAS 98 11691-11696.

Demski LS 1973 Feeding and aggressive behavior evoked by hypothalamic stimulation in a cichlid fish. Comparative Biochemistry and Physiology 44 685-692.

Dlugos CA \& Rabin RA 2003 Ethanol effects on three strains of zebrafish: model system for genetic investigations. Pharmacology, Biochemistry and Behavior 74 471-480.

Dores RM, Lecaude S, Bauer D \& Danielson PB 2002 Analyzing the evolution of the opioid/orphanin gene family. Mass Spectrometry Reviews 21 220-243.

Evans CJ, Keith DE Jr, Morrison H, Magendzo K \& Edwards RH 1992 Cloning of a delta opioid receptor by functional expression. Science 258 1952-1955.

Fishman MC 2001 Zebrafish - the canonical vertebrate. Science 294 1290-1291.

Fukuda K, Terasako K, Kato S \& Kenjiro M 1995 Identification of the amino acid residues involved in selective agonist binding in the first extracellular loop of the $\delta$ and $\mu$ opioid receptors. FEBS Letters 373 $177-181$ 
Golling G, Amsterdam A, Sun Z, Antonelli M, Maldonado E, Chen W, Burgess S, Haldi M, Artzt K, Farrington S et al. 2002 Insertional mutagenesis in zebrafish rapidly identifies genes essential for early vertebrate development. Nature Genetics 31 135-140.

Gonzalez-Nuñez V, Gonzalez-Sarmiento R \& Rodriguez RE $2003 a$ Characterization of zebrafish proenkephalin reveals novel opioid sequences. Molecular Brain Research 114 31-39.

Gonzalez-Nuñez V, Gonzalez-Sarmiento R \& Rodriguez RE $2003 b$ Cloning and characterization of a full-length pronociceptin in zebrafish: evidence of the existence of two different nociceptin sequences in the same precursor. Biochimica et Biophysica Acta - Gene Structure and Expression 1629 114-118.

Gonzalez-Nuñez V, Gonzalez-Sarmiento R \& Rodriguez RE $2003 c$ Identification of two proopiomelanocortin genes in zebrafish Danio rerio. Molecular Brain Research 120 1-8.

Grossman A \& Rees LH 1983 The neuroendocrinology of opioid peptides. British Medical Bulletin 39 83-88.

Harrison LM, Kastin AJ, Weber JT, Banks WA, Hurley DL \& Zadina JE 1994 The opiate system in invertebrates. Peptides 15 1309-1329.

Ingham PW 1997 Zebrafish genetics and its implications for understanding vertebrate development. Human Molecular Genetics 6 $1755-1760$.

Kieffer BL, Befort K, Gaveriaux-Ruff C \& Hirth CG 1992 The deltaopioid receptor: isolation of a cDNA by expression cloning and pharmacological characterization. PNAS 89 12048-12052.

Knapp RJ, Malatynska E, Fang L, Li X, Babin E, Nguyen M, Santoro G, Varga EV, Hruby VJ, Roeske WR et al. 1994 Identification of a human delta opioid receptor: cloning and expression. Life Sciences 54 PL463-PL469.

Kumar S, Tamura K, Jakobsen IB \& Nei M 2001 MEGA2: molecular evolutionary genetics analysis software. Bioinformatics 12 1244-1245.

Mansour A, Thompson RC, Akil H \& Watson SJ 1993 Delta opioid receptor mRNA distribution in the brain: comparison to delta receptor binding and proenkephalin mRNA. Journal of Chemical Neuroanatomy 6 351-362.

Mansour A, Fox CA, Burke S, Meng F, Thompson RC, Akil H \& Watson SJ $1994 \mu, \delta$ and $\kappa$ opioid receptor mRNA expression in the rat CNS: an in situ hybridization study. Journal of Comparative Neurology 350 412-438.

Mansour A, Hoversten MT, Taylor LP, Watson SJ \& Akil H 1995 The cloned mu, delta and kappa receptors and their endogenous ligands: evidence for two opioid peptide recognition cores. Brain Research 700 89-98.

Meek J \& Nieuwenhuys R 1998 Holostean and teleosts. In The Central Nervous System of Vertebrates, vol 2, pp 759-785. Eds R Nieuwenhuys, HJ Ten Donkelaar \& C Nicolson. Berlin: Springer-Verlag pp 873-900.

Meng F, Ueda Y, Hoversten MT, Thompson RC, Taylor L, Watson SJ \& Akil H 1996 Mapping the receptor domains critical for the binding selectivity of $\delta$ opioid receptor ligands. European Journal of Pharmacology 311 285-292.

Metzger TG \& Ferguson DM 1995 On the role of extracellular loops of opioid receptors in conferring ligand selectivity. FEBS Letters 375 1-4.

Mukherjee S, Baker BI, Bird DJ \& Buckingham JC 1987 Hypothalamopituitary-interrenal responses to opioid substances in the trout. 2. Effects of morphine and $\left[\mathrm{D}-\mathrm{Ala}^{2}, \mathrm{Met}^{5}\right]$-enkephalinamide on plasma cortisol titres in vivo. General and Comparative Endocrinology 68 40-48.

Pasternak GW 1988. The Opiate Receptors, Clifton, New Jersey: Humana Press.

Pepin MC, Yue SY, Roberts E, Wahlestedt C \& Walker P 1997 Novel restoration of function mutagenesis strategy to identify amino acids of the $\delta$-opioid receptor involved in ligand binding. Journal of Biological Chemistry 272 9260-9267.

Pert CB, Aposhian D \& Snyder SH 1974 Phylogenetic distribution of opiate receptor binding. Brain Research 75 356-361.

Pichler FB, Laurenson S, Williams LC, Dodd A, Copp BR \& Love DR 2003 Chemical discovery and global gene expression analysis in zebrafish. Nature Biotechnology 21 879-883.
Pimpinelli F, Parenti M, Guzzi F, Piva F, Hokfelt T \& Maggia R 2006 Presence of delta opioid receptors on a subset of hypothalamic gonadotropin releasing hormone (GnRH) neurons. Brain Research 1070 15-23.

Porteros A, García-Isidoro M, Barrallo A, Gonzalez Sarmiento R \& Rodríguez RE 1999 Expression of ZFOR1, a delta-opioid receptor, in the central nervous system of the zebrafish (Danio rerio). Journal of Comparative Neurology 412 429-438.

Pu S, Horvath TL, Diano S, Naftolin F, Kalra PS \& Kalra SP 1997 Evidence showing that $\beta$-endorphin regulates cyclic guanosine $3^{\prime}$, $5^{\prime}$-monophosphate (cGMP) efflux: anatomical and functional support for an interaction between opiates and nitric oxide. Endocrinology 138 1537-1543.

Rodriguez RE, Barrallo A, Garcia-Malvar F, McFadyen IJ, GonzalezSarmiento R \& Traynor JR 2000 Characterization of ZFOR1, a putative delta-opioid receptor from the teleost zebrafish (Danio rerio). Neuroscience Letters 288 207-210.

Rosenblum PM, Goos HJT \& Peter RE 1994 Regional distribution and in vitro secretion of Salmon and Chicken II gonadotropin releasing hormones from the brain and pituitary of juvenile and adult Goldfish, Carassius auratus. General and Comparative Endocrinology 93 369-379.

Sambrook J \& Russell RW 2001. Molecular Cloning: A Laboratory Manual, New York: Cold Spring Harbor Laboratory.

Simantov R, Goodman R, Aposhian D \& Snyder SH 1976 Phylogenetic distribution of a morphine-like peptide, 'enkephalin'. Brain Research 111 204-211.

Stefano GB, Salzet B \& Fricchione GL 1998 Enkelytin and opioid peptide association in invertebrates and vertebrates: immune activation and pain. Immunology Today 19 265-268.

Stevens CW 2004 Opioid research in amphibians: an alternative pain model yielding insights on the evolution of opioid receptors. Brain Research Reviews 46 204-215.

Traynor JR \& Nahorski SR 1995 Modulation by mu-opioid agonists of guanosine- $5^{\prime}-0-\left(3-\left[{ }^{35} \mathrm{~S}\right]\right.$ thio $)$ triphosphate binding to membranes from human neuroblastoma SH-SY5Y cells. Molecular Pharmacology 47 848-854.

Valiquette M, Vu HK, Yue SY, Wahlestedt C \& Walker P 1996 Involvement of Trp-284, Val-296 and Val-297 of the human $\delta$ opioid receptor in binding of $\delta$-selective ligands. Journal of Biological Chemistry 271 18789-18796.

Varga EV, Li X, Stropova D, Zalewska T, Landsman RS, Knapp RJ, Malatynska E, Kawai K, Mizusura A, Nagase H et al. 1996 The third extracellular loop of the human delta-opioid receptor determines the selectivity of delta-opioid agonists. Molecular Pharmacology $\mathbf{5 0}$ $1619-1624$.

Waldhoer M, Bartlett SE \& Whistler JL 2004 Opioid receptors. Annual Review of Biochemistry 73 953-990.

Wang JB, Imai Y, Eppler CM, Gregor P, Spivak CE \& Uhl GR 1993 mu opiate receptor: cDNA cloning and expression. PNAS $\mathbf{9 0}$ 10230-10234.

Wang WM, Shahrestanifar M, Jin J \& Howells RD 1995 Studies on $\mu$ and $\delta$ opioid receptor selectivity utilizing chimeric and sitemutagenized receptors. PNAS 92 12436-12440.

Wullimann MF, Rupp B \& Reichert H 1996. Neuroanatomy of the Zebrafish Brain, Basel: Birkhauser Verlag.

Yasuda K, Raynor K, Kong H, Breder CD, Takeda J, Reisine T \& Bell GI 1993 Cloning and functional comparison of $\kappa$ and $\delta$ opioid receptors from mouse brain. PNAS 90 6736-6740.

Zhang S, Tong Y, Tian M, Dehaven RN, Cortesburgos L, Mansson E, Simonin F, Kieffer B \& Yu L 1998 Dynorphin A as a potential endogenous ligand for four members of the opioid receptor gene family. Journal of Pharmacology and Experimental Therapeutics 286 136-141.

Accepted 8 August 2006

Made available online as an Accepted Preprint 7 September 2006 